\title{
Impact of Frontline Demonstration on Arecanut Root Grub Management
}

\author{
B.C. Hanumanthaswamy ${ }^{1}$, Nagarajappa Adivappar ${ }^{1}$ and Pradeep Gopakkali ${ }^{2 *}$ \\ ${ }^{1}$ Department of Horticulture, KVK, Shivamogga, Karnataka, India \\ ${ }^{2}$ Department of Agronomy, UAHS, Shivamogga, Karnataka, India \\ *Corresponding author
}

\begin{abstract}
A B S T R A C T
The frontline demonstration was conducted to evaluate the efficacy of insecticide

Keywords

Arecanut,

Root grub, Demonstrated technology, Incidence, Farmers' practice.

Article Info

Accepted:

27 June 2017

Available Online:

10 August 2017

Imidachloprid and neem cake against root grub infesting arecanut at Malnad areas of Shivamogga district, Karnataka during 2012 to 2016. The results revealed that in demonstration plots the combined application of Imidachloprid + neemcake application for root grub over five years constantly resulted in lower incidence compared to farmers' plots. In the treated gardens the trees showed the symptoms of untapering towards tip, larger internodes, greenish colored healthy and normal sized leaves and the gardens were completely free from root grub infestation. The highest yield was recorded in demonstration plots $(10.20 \mathrm{q} / \mathrm{ha})$ as compared to farmers' plots $(7.81 \mathrm{q} / \mathrm{ha})$, registering an increase in yield of 27.17 per cent over farmers' practice. As far as the economics is concerned, the demonstrated technology gave the highest cost benefit ratio (1:4.10) as compared to farmers' practice (1:3.69). Group meetings were conducted to spread awareness among neighboring farmers about the time and method of application of treatments for the effective management of arecanut root grub. Farmers were impressed with the higher yield and root grub free gardens.
\end{abstract}

\section{Introduction}

Arecanut is an important plantation crop grown in irrigated tracts of coastal areas of India. It is cultivated in large scale in Malnad districts of Karnataka, particularly in Shivamogga. Farmers were getting low yield in spite of good cultivation practices, therefore they wanted to remove the arecanut trees and grow forest trees.

Although no major problems were observed in their cultivation, observations indicated that the trees show the symptoms like tapering towards tip, short internodes and yellow colored little leaves. Based on the symptoms the trees were examined and effected roots were severely infested with root grubs.

However, the Profitable cultivation was hindered mainly because of the increasing menace of pests and diseases and thereby yield losses. Among insect pests root grub is economically the most important and regular pest on arecanut (Hanumanthaswamy et al., 2001). Therefore, it was felt necessary to provide suitable management strategy. Indiscriminate application of insecticides against root grub of arecanut resulted in the mortality of natural enemies and other useful 
fauna. Thus, pest problem increased alarmingly and need was felt to develop effective alternative means of pest management. Based on the mandates of KVK, Shivamogga the front line demonstration was conducted in farmers' field during 2012 to 2016 to show farmers the effectiveness of pest management strategies.

\section{Materials and Methods}

The front line demonstration was conducted in farmers' field during August-September, 2012 to 2016 in 15 hectare in 31 farmers' field at different villages of Sagar taluk, Shivamogga district. Regular farmers meeting, training programmes, field visit and group discussions were conducted which helped farmers in identifying the stages of pest, nature of damage, critical stages for intervention and enlighten the farmers the benefits of the demonstrated technology in reducing the root grub incidence. Based on symptoms the trees were uprooted and examined. The affected roots were severely infested with root grubs. The demonstration was conducted in severely affected arecanut gardens by imposing different treatments. In demonstration plot the management strategy included proper dosage, proper method and right time of application of neem cake @ $2 \mathrm{~kg}$ /tree and Imidachloprid @ $0.5 \mathrm{ml} /$ litre of water (3 litre solution / tree). The farmers practice included indiscriminate use of insecticides compared to selective insecticides followed in front line demonstration. The incidence (number of grubs / tree) of root grubs was recorded on 30 and 60 days after application of insecticides in both the methods. The demonstration was culminated by organizing a formers meet where farmers visually observed the results and compared the trees in demonstrated and check plots. Regular field visits and group discussions were conducted which help the farmers in identifying the stages of pest, nature of damage and right time for intervention and importance of the technology.

\section{Results and Discussion}

The results revealed that the farmers practice certainly experienced more number of grubs / tree as compared to demonstrated one. In demonstrated technology (Imidachloprid + neem cake treatment), 30 days and 60 days after treatment recorded lower number of grubs when compared to farmers practice. The maximum protection was afforded by combined application of Imidachloprid treatment + neem cake application. Combined application of neem cake + Imidachloprid for root grub over five years constantly resulted in lower incidence compared to indiscriminate use of insecticides. The demonstrated technology is effective compared to farmers practice mainly because of the intervention made at right time in August-September when the first instars grubs are in the upper surface of soil, Imidachloprid application by root absorption technique, neem cake application for effective repellent and anti-feedent action against root grubs. Though insecticidal application was not taken up at right time, right quantity and in right method the farmers practice resulted in higher number of grubs. Thus finally resulted in more reduction of grubs in demonstrated technology compared to farmers' practice of plant protection. In terms of number of grubs' reduction on the trees on 60 days after treatment, there was decrease over farmers practice to the extent of $81.07 \%$ in the trees receiving application of Imidachloprid + neem cake (Table 1). The demonstrated practice resulted in substantial reduction in root grub incidence.

Similarly, Kalidas (2003) observed less incidence of slug caterpillar by soil application of Phorate and root feeding technique of monocrotophos in oil palm. The treatment effect was reflected in nut yields. 
Table.1 Evaluation of management strategies for arecanut root grub menace

\begin{tabular}{|c|c|c|c|c|c|c|c|c|c|c|c|c|c|c|c|c|c|c|}
\hline \multirow{3}{*}{ Strategies } & \multirow{3}{*}{$\begin{array}{l}\text { Method of } \\
\text { application }\end{array}$} & \multirow{3}{*}{ Dosage } & \multicolumn{10}{|c|}{ Mean No. of grubs / tree } & \multirow{2}{*}{\multicolumn{5}{|c|}{$\begin{array}{l}\text { \% reduction over farmers practice at } \\
60 \text { days after treatment }\end{array}$}} & \multirow{3}{*}{$\begin{array}{c}\text { Mean } \\
(\% \\
\text { reducti } \\
\text { on) }\end{array}$} \\
\hline & & & \multicolumn{5}{|c|}{30 days after treatment } & \multicolumn{5}{|c|}{60 days after treatment } & & & & & & \\
\hline & & & 2012 & 2013 & 2014 & 2015 & 2016 & 2012 & 2013 & 2014 & 2015 & 2016 & 2012 & 2013 & 2014 & 2015 & 2016 & \\
\hline Farmers practice & $\begin{array}{c}\text { Broad } \\
\text { casting / } \\
\text { spraying }\end{array}$ & $\begin{array}{l}5-10 \mathrm{~kg} \text { or } \\
2-3 l / \text { acre }\end{array}$ & 6.80 & 7.00 & 8.50 & 6.00 & 5.10 & 8.20 & 10.50 & 9.10 & 8.80 & 7.60 & - & - & - & - & - & -- \\
\hline $\begin{array}{l}\text { Demonstrated } \\
\text { technology } \\
\text { (Imidachloprid + } \\
\text { Neemcake } \\
\text { application) }\end{array}$ & $\begin{array}{c}\text { Root } \\
\text { absorption }+ \\
\text { Soil } \\
\text { application }\end{array}$ & $\begin{array}{c}1.5 \mathrm{ml} / \\
\text { tree }+ \\
2 \mathrm{~kg} / \text { tree }\end{array}$ & 3.50 & 2.50 & 1.80 & 1.90 & 1.70 & 2.40 & 1.80 & 1.30 & 1.60 & 1.20 & 70.73 & 82.86 & 85.71 & 81.82 & 84.21 & 81.07 \\
\hline
\end{tabular}

Table.2 Cost Economic Analysis of Root Grub Management

\begin{tabular}{|c|c|c|c|c|c|c|c|c|c|c|c|c|}
\hline \multirow{2}{*}{ Parameters } & \multicolumn{5}{|c|}{ Demonstrated technology } & \multirow{2}{*}{ Mean } & \multicolumn{5}{|c|}{ Farmers Practice } & \multirow{2}{*}{ Mean } \\
\hline & 2012 & 2013 & 2014 & 2015 & 2016 & & 2012 & 2013 & 2014 & 2015 & 2016 & \\
\hline Average yield (q/ha) & 10.00 & 10.00 & 10.80 & 12.10 & 8.10 & 10.20 & 6.75 & 8.00 & 8.50 & 9.40 & 6.40 & 7.81 \\
\hline $\begin{array}{l}\text { \% increase in yield over } \\
\text { farmers' practice }\end{array}$ & 32.50 & 25.00 & 27.06 & 28.72 & 26.56 & 27.97 & - & - & - & - & - & -- \\
\hline Cost of production (Rs.) & 65000 & 63000 & 62200 & 75400 & 47800 & 62680 & 55000 & 54000 & 52600 & 67000 & 41800 & 54080 \\
\hline Gross income (Rs.) & 120000 & 200000 & 388800 & 314600 & 243000 & 253280 & 81000 & 160000 & 306000 & 244400 & 192000 & 196680 \\
\hline Net profit (Rs.) & 55000 & 137000 & 326600 & 239200 & 195200 & 190600 & 26000 & 106000 & 253400 & 177400 & 150200 & 142600 \\
\hline B:C ratio & 1.84 & 3.17 & 6.25 & 4.17 & 5.06 & 4.10 & 1.47 & 2.96 & 5.82 & 3.65 & 4.57 & 3.69 \\
\hline
\end{tabular}


The maximum yield was recorded in the trees where neemcake was applied and Imidachloprid was treated under demonstrated technology $(10.20 \mathrm{q} / \mathrm{ha})$ as compared to farmers practice $(7.81 \mathrm{q} / \mathrm{ha})$, registering an increase in yield of 27.97 per cent over farmers practice (Table 2).

The difference in yield in two regimes may be due to the difference in pest management operations (Hanumanthaswamy et al., 2016). The cost of production was slightly more under demonstrated plots (Rs. 62,680/ha) in comparison to farmers practice (Rs. $54,080 / \mathrm{ha})$.

The gross income obtained was Rs.2,53,280/ha and Rs. 1,96,680/ha in demonstrated technology and farmers method respectively. The net profit of Rs. 1,90,600/ha in demonstrated technology as compared to farmers' method which was lesser profit of Rs. 1,42,600/ha. That means just by combined application of Imidachloprid and neem cake an additional net return of Rs.48,000/ha could be obtained. The cost: benefit ratio obtained was 4.10 as against 3.69 in farmers' practice (Table 2).
The study indicated that the trees in the treated gardens showing the symptoms of untapering towards tip, larger internodes, greenish colored healthy and normal sized leave and the garden was completely free from root grubs infestation. Farmers were impressed with the higher yield and root grub free gardens. They motivated the other farmers of their surrounding villages to go for this method to get rid of arecanut root grub menace.

\section{References}

Hanumanthaswamy, B.C., Chandrashekar, S.Y. and Sunil, C., 2001. Notorious pest of arecanut: Root grub. Malenadu Mitra, 159:2

Hanumanthaswamy, B.C., Sreenivasa, K.R. and Nagarajappa Adivappar, 2016. Impact of demonstrations on arecanut root grub management in Shivamogga district. Presented in $1^{\text {st }}$ KVK Symposium Zone VIII, 21-22 January, 2016 at UAS, Dharwad.

Kalidas, P., 2003. Frontier area of entomological research. B. Subramanyam and V.V. Ramamurthy (Eds). IARI, New Delhi, India/88-89 pp.

\section{How to cite this article:}

Hanumanthaswamy, B.C., Nagarajappa Adivappar and Pradeep Gopakkali. 2017. Impact of Frontline Demonstration on Arecanut Root Grub Management. Int.J.Curr.Microbiol.App.Sci. 6(8): 3422-3425. doi: https://doi.org/10.20546/ijcmas.2017.608.410 